\title{
DARIA ZARZECZNA
}

Uniwersytet Szczeciński, Wydział Filologiczny

Szczecin

d.zarzeczna@onet.pl

\section{Sukienka w kolorze zmrożonego sorbetu mango - czyli kilka słów o barwach na blogu modowym Macademian Girl}

Słowa k1uczowe

polszczyzna współczesna, niepodstawowe nazwy barw w języku polskim, język blogów modowych

Keywords

contemporary Polish language, non-basic Polish colour names, language of fashion blogs

1.

Bogactwo wzorów i faktur, ale przede wszystkim mnogość kolorów to cechy charakterystyczne Macademian Girl, czyli Tamary Gonzalez Perei ${ }^{1}$. Pochodząca ze Szczecina 27-letnia dziennikarka modowa i blogerka już na początku swojej medialnej drogi, za sprawą niezwykłych stylizacji pełnych żywych kolorów, została okrzyknięta mianem ,rajskiego ptaka”. Od 2011 roku konsekwentnie prezentuje na blogu swój niepowtarzalny, barwny styl, który sama określa jako „kolorowy glamour”. Inspiracją dla blogerki jest przede wszystkim otaczający ją świat - pełen rozmaitych barw, subtelnych odcieni i niecodziennych połączeń, z których czerpie garściami, tworząc niezliczone stylizacje.

\footnotetext{
${ }^{1}$ Macademian Girl, dostęp 28.11.2016, http://macademiangirl.com.
} 
To właśnie owa różnorodność pojawiających się na blogu postów i oryginalny sposób opisu prezentowanych strojów stały się impulsem do napisania niniejszego artykułu, w którym analizie i interpretacji zostaną poddane nazwy barw, służące autorce do malowania obrazów słownych. Nazwy kolorów są bowiem na blogu Macademian Girl narzędziem do tworzenia pobudzających wyobraźnię, a zarazem uruchamiających nieograniczone skojarzenia opisów, dla których obraz jest jedynie dodatkiem. Wyekscerpowany materiał badawczy stanowią treści 91 postów zamieszczonych w zakładce „Stylizacje” i opublikowanych na blogu w okresie od 3 stycznia 2015 roku do 9 czerwca 2016 roku. Publikowane przez autorkę bloga wpisy są krótkie (ich objętość nie przekracza 200 wyrazów tekstowych), tym bardziej godne uwagi jest więc wykorzystanie bogatego zestawu nazw odnoszących się do palety barw.

Przedstawiane na blogu treści prezentowane są w taki sposób, by najpierw zainteresować czytelnika płaszczyzną językową tekstu, uruchomić jego wyobraźnię i poddać subtelnie podsuwanym przez autorkę skojarzeniom. Temu służy m.in. tytuł - jak na przykład: Zimowa kraina Inków czy Córka czerwonego kapelusznika - który każdorazowo wprowadza odbiorców w zaczarowany świat mody. Co prawda, najpierw pojawia się zdjęcie, na którym zobaczyć można niektóre elementy stroju, stanowi ono jednak jedynie zapowiedź, swoistą wskazówkę do treści, które mają się ukazać. Pod zdjęciem zamieszczany jest tekst, w którym autorka drobiazgowo opisuje kolejne elementy stylizacji, a także wskazuje źródła swoich inspiracji: Kiedy wymyślałam dzisiejsza stylizację, sięgnęłam po albumy z kolażami Henriego Matisse'a. Francuski artysta wycinat elementy swoich prac z barwnego papieru, a potem zestawiat je z czernia, biela i szarościa. Dzięki temu wszystkie kolory stawaty się jeszcze wyrazistsze i rozwibrowane! (Owocowa tęcza, 7 lutego 2016). Blogerka często dzieli się z czytelnikami własnymi przemyśleniami i skojarzeniami, które stają się dla niej bodźcem do tworzenia kolejnych kreacji: Wyobraziłam sobie, że właśnie szykuję się na impreze po drugiej stronie lustra i wybrałam odpowiednio spektakularna sukienkę. Ilość wzorów wręcz przyprawia o zawrót głowy! Motywy mknacych karet i królewskich ornamentów zostały zapisane na materiale jak prawdziwa bajka o pięknej księżniczce. A to wszystko na tle przypominającym tapety z najokazalszych pałaców. (Prints all over, 19 stycznia 2015). Tak obrazowe i plastyczne wprowadzenie uzupełniają liczne fotografie, które stanowią wizualizację opisanych treści. Pod każdym postem umieszczanych jest zazwyczaj około 25-30 zdjęć, na których prezentowane są nie tylko poszczególne elementy stylizacji, ale również przestrzeń, będąca tłem do sesji zdjęciowych. W zakończeniu wpisu zawsze pojawiają się wskazówki, jak można ubrać się podobnie oraz informacje, z jakich sklepów pochodzą zamieszczone na fotografiach stroje. Każdy post fani Macademian Girl mogą komentować pojawiają się tam pytania do blogerki, prośby o porady dotyczące sposobu ubierania się oraz wyrazy podziwu dla stylu Tamary Gonzalez Perei. 
W 1969 roku dwaj amerykańscy antropologowie i lingwiści, Brent Berlin i Paul Kay, w pracy Basic Color Terms zaprezentowali pionierską klasyfikację barw, którą oparli na analizie niemal stu języków świata ${ }^{2}$. Na podstawie przeprowadzonych badań ustalili indeks jedenastu podstawowych barw, do których zaliczyli następujące kolory: biały, czarny, czerwony, zielony, żółty, niebieski, brąowy, fioletowy, pomarańczowy, różowy oraz szary. Wskazali przy tym, że nazwy barw pojawiają się w poszczególnych językach w określonym porządku, co jest wynikiem tzw. hierarchii implikacyjnej leksyki barw. Ponadto badacze podali cztery warunki, jakie musi spełniać podstawowa nazwa barwy:

a) prostota morfologiczna (warunku tego nie spełniają nazwy barw, w obrębie których znaczenie podstawowe nazwy wynika z sumy znaczeń jej części, np. ciemnoczerwony);

b) brak semantycznego przyporządkowania innej nazwie barwy (warunku tego nie będą spełniać nazwy takie jak rubinowy, amarantowy, które stanowią niepodstawowy semantyczny wariant czerwieni);

c) szeroki zakres łączliwości (nazwy takie jak blond czy rudy, które odnoszą się niemal wyłącznie do koloru włosów odznaczają się zredukowaną łączliwością, a tym samym nie spełniają powyższego warunku);

d) psychologia barwy, czyli zapisane w psychice ludzkiej nazwy wzorców kolorów, które są trwale zakodowane w pamięci użytkowników języka i jako pierwsze przychodzą na myśl przy ocenie danej barwy (warunku tego nie spełniają nazwy takie jak antracytowy czy kobaltowy) ${ }^{3}$.

Zaprezentowana przez badaczy klasyfikacja barw podstawowych do dziś pozostaje fundamentalnym podziałem kolorów w badaniach językoznawczych, choć niejednokrotnie była poddawana krytyce, a wielu językoznawców zaproponowało zupełnie inny kierunek badań $^{4}$. Z przedstawionego przez uczonych uporządkowania czerpali również polscy językoznawcy, m.in. Ryszard Tokarski, który w przytoczonym zestawieniu dokonał pewnej zmiany, sytuując barwę szarą na ósmym miejscu w hierarchii. Wskazał bowiem, że w polszczyźnie nazwa szary jest jedyną nazwą prasłowiańską, która istniała w języku na długo przed wprowadzeniem zapożyczeń, takich jak: pomarańczowy czy różowy ${ }^{5}$. Z perspektywy niniejszego opracowania najistotniejsze wydają się jednak założenia, jakie Tokarski poczynił w odniesieniu do palety barw niepodstawowych, która odznacza się znacznie większą

2 Brent Berlin, Paul Kay, Basic Color Terms: Their Universality and Evolution (Berkeley: University of California Press, 1969).

${ }^{3}$ Ryszard Tokarski, Semantyka barw we wspótczesnej polszczyźnie (Lublin: Wydawnictwo Uniwersytetu Marii Skłodowskiej-Curie, 2004), 19.

${ }^{4}$ Ewa Komorowska, Barwa w języku polskim i rosyjskim: rozważania semantyczne (Szczecin: Wydawnictwo Naukowe Uniwersytetu Szczecińskiego, 2010), 58.

5 Tokarski, Semantyka barw, 20. 
liczebnością i różnorodnością, i która jest znacznie liczniej reprezentowana w badanym materiale. Zaproponowany przez badacza podział znaczeniowych źródeł niepodstawowych nazw barw stanowić będzie fundament przedstawionej klasyfikacji, która zostanie jednak rozbudowana o inne typy motywacji, jakie ujawniły się w toku prowadzonej analizy.

Wyekscerpowany do analizy i interpretacji materiał badawczy stanowi łącznie 117 leksemów, zastosowanych w 322 realizacjach tekstowych. Wśród analizowanych jednostek językowych znalazły się pojedyncze leksemy, konstrukcje analityczne, a także struktury deskrypcyjne, wyrażane najczęściej w formie porównań. Pośród 117 wybranych do analizy leksemów znalazło się jedenaście nazw barw podstawowych, którymi Macademian Girl posłużyła się łącznie w 116 realizacjach tekstowych, co stanowi 36\% wszystkich użyć. Pozostałe 64\% stanowią derywaty przymiotnikowe prymarnie lub wtórnie odnoszące się do nazw kolorów (np. antracytowy, fuksjowy, szmaragdowy), formy z komponentem nazwy barwy podstawowej, wskazujące na intensywność lub poziom światłości/ciemności danego koloru (np. jaskraworóżowy, przykurzona czerwień, świetlisty niebieski), struktury dookreślające, zbudowane z nazwy barwy podstawowej i nazwy barwy niepodstawowej (np. bananowa żótć, kwarcowy róż, kobaltowy niebieski) oraz struktury deskrypcyjne (kolor zmrożonego sorbetu mango, barwa oszronionych liści).

Stosunkowo niewiele nazw zawiera komponenty wskazujące na intensywność opisywanej barwy. Z badanego materiału wyodrębniono 14 takich nazw, co stanowi niecałe $12 \%$ analizowanych jednostek. Dookreślenia mające na celu uszczegółowienie stopnia nasycenia danej barwy odnoszą się jedynie do 4 pól kolorystycznych: pola czerwieni (głęboki czerwony kolor, jaskrawo-czerwony, nasycona czerwień, przykurzona czerwień, soczysta czerwień); pola żółci (neonowo żółty, soczysta żółć); pola pomarańczu (nasycony odcień pomarańczu, soczysty odcień pomarańczu, wyrazisty pomarańcz, zgaszony pomarańcz) oraz pola różu (hot pink - dosł. gorący róż, intensywny róż). Nieliczne są również przykłady nazw barw, które służą określeniu poziomu jasności bądź ciemności danej barwy (3): rozbielo$n y$, rozbielony róż oraz świetlisty niebieski ${ }^{6}$. Pojedyncze przykłady nazw barw, w których pojawia się opisowa definicja stopnia intensywności oraz jasności, świadczy niewątpliwie o dogłębnej znajomości palety barw i wiedzy blogerki na temat najdrobniejszych niuansów kolorystycznych. Zamiast stosować definicje opisowe, w obrębie których dochodzi do przyporządkowania niepodstawowej nazwy barwy nazwie podstawowej, autorka używa określeń odnoszących się do konkretnych obiektów z otaczającego ją świata ${ }^{7}$, co ukażą klasyfikacje semantyczne zaprezentowane w toku dalszej analizy.

Przejdźmy zatem do zbadania nazw barw motywowanych słowotwórczo poprzez wskazanie wzorca kolorystycznego w otaczającym świecie. Ryszard Tokarski podkreśla,

\footnotetext{
${ }^{6}$ Wszystkie zaklasyfikowane do tej grupy nazwy mają zasygnalizować nadanie jaśniejszego odcienia (rozbielić 1. 'nadać jaśniejszy odcień przez dodanie białej farby'; 2. 'uczynić jaśniejszym, rozjaśnić, rozświetlić' SJPSz III, 73; świetlisty 'utworzony ze światła, pełen światła, jaśniejący’ SJPSz III, 432).

7 Tokarski, Semantyka barw, 144.
} 
że punktem wyjścia dla niepodstawowych nazw kolorów są obiekty istniejące w otaczającym człowieka świecie, które można powiązać w pewne klasy. Regularności, jakie dają się zaobserwować w definiowaniu nazw barw, dotyczą ,po pierwsze, ogólnych tendencji znaczeniowych, jakie istnieją przy tworzeniu niepodstawowych nazw barw oraz, po drugie, kręgów znaczeniowych słownictwa, które zdają się szczególnie predestynowane do rozwijania leksyki kolorów" . Analiza nazw barw motywowanych odniesieniami do otaczającego świata pozwoliła wyodrębnić 10 następujących grup:

a) nazwy barw motywowane nazwami obiektów, z których niegdyś wytwarzano barwniki ${ }^{9}$ :

należące do pola czerwieni: karminowy (karmin 'jaskrawoczerwony barwnik otrzymywany z koszenili' SJPSz I, 834) ${ }^{10}$;

należące do pola barwy niebieskiej: kobalt, kobaltowy, elektryzujący odcień kobaltu, głęboki kobaltowy odcień, zimny kobaltowy, kobaltowy niebieski (błękit kobaltowy 'glinian kobaltu, niebieska farba mineralna' SJPD III, 772); szlachetne indygo, sproszkowane indygo (indygo "niebieski barwnik kadziowy otrzymywany dawniej z liści indygowca farbiarskiego' SJPSz I, 737); ultramaryna, zimny odcień ultramaryny (ultramaryna 'otrzymywany syntetycznie glinokrzemian sodowy zawierający siarkę, o zabarwieniu od niebieskiego do różowego; niebieski jest cennym barwnikiem stosowanym w przemyśle papierniczym, cukrowniczym, lakierniczym' SJPD IX, 550); błękit, chtodny błękit (błękit 'barwnik niebieskiego koloru stosowany jako farba malarska i drukarska' SJPSz I, 168);

należące do pola brazu: ochra' ${ }^{11}$ (ochra 'żółta lub brunatna farba otrzymywana z glinki w tych kolorach i używana w malarstwie, do drukowania tkanin, w przemyśle kosmetycznym itp.' SJPSz II, 417);

należące do pola pomarańczu: oranż (oranż metylowy 'substancja organiczna, barwnik koloru pomarańczowego stosowany jako wskaźnik w laboratoriach chemicznych' SJPD V, 1069-1070);

8 Tamże, 145.

${ }^{9}$ Klasyfikacji nazw, które włączono do tej kategorii, dokonano na podstawie ustaleń Agnieszki Madei (por. Agnieszka Madeja, „Skąd pochodzą polskie nazwy kolorów”, Postscriptum Polonistyczne 2 (2010): 197-217).

${ }^{10}$ Definicje czerpano przede wszystkim ze Słownika języka polskiego PWN, red. Mieczysław Szymczak, t. I-III (Warszawa: Wydawnictwo Naukowe PWN, 1996) (w skrócie SJPSz) oraz Słownika języka polskiego, red. Witold Doroszewski, t. I-XI (Warszawa: Państwowe Wydawnictwo „Wiedza Powszechna”, 1958-1969) (w skrócie SJPD). W kilku przypadkach posłużono się definicjami zawartymi w Słowniku języka polskiego PWN (w skrócie: SJP PWN online) ukazującym się w wersji elektronicznej, dostęp 28.11.2016, http://sjp.pwn.pl/.

11 Ochra może przybierać barwę żółtą lub brunatną, w tym wypadku nazwa została zastosowana na określenie koloru należącego do pola brązu. 
b) nazwy barw motywowane nazwami kamieni szlachetnych i minerałów:

należące do pola czerwieni: rubinowy (rubin 'kamień szlachetny o ciemnoczerwonej barwie, ceniony w jubilerstwie i przemyśle precyzyjnym' SJPSz III, 132);

należące do pola zieleni: malachitowa zieleń (malachit 'minerał barwy zielonej, o szklistym połysku' SJPSz II, 90); szmaragd, szmaragdowy (szmaragd 'przezroczysty minerał barwy zielonej będący cennym kamieniem szlachetnym' SJPSz III, 389);

należące do pola barwy niebieskiej: turkus, turkusowy (turkus 'minerał barwy niebieskawej lub niebieskozielonej, o szklistym albo woskowym połysku' SJPSz III, 514);

należace do pola fioletu: ametystowy (ametyst 'przezroczysta fioletowa odmiana kwarcu, minerał, kamień półszlachetny stosowany w jubilerstwie' SJPSz I, 41); należące do pola różu: kwarcowy róż (kwarc 'najpospolitszy minerał skorupy ziemskiej bezbarwny lub zabarwiony’ SJPSz I, 1027; do grupy kwarców zaliczają się m.in. różnokolorowe odmiany „zanieczyszczone” rozmaitymi domieszkami, takie jak fioletowy ametyst, brązowy kwarc dymny, czarny morion, żółty cytryn, kwarc niebieski czy kwarc różowy ${ }^{12}$ );

należące do pola szarości: antracyt (antracyt 'gatunek węgla kamiennego mający barwę szaroczarną o blasku metalicznym' SJPD I, 151);

c) nazwy barw motywowane nazwami metali szlachetnych i półszlachetnych oraz związków metali:

należace do pola bieli: srebrny, srebro (srebro 'metal szlachetny, biały o pięknym połysku' SJPD VIII, 666)

należące do pola żółci: złoto, złoty, złoto w odcieniu nude, jasne złoto (złoto 'metal szlachetny o żółtym, mocnym połysku' SJPD X, 1155-1157);

należące do pola brązu: miedź (miedź 'metal ciężki, czerwonawobrązowy' SJPD IV, 635);

należące do pola szarości: platyna (platyna 'metal szlachetny, jasnoszary' SJPD VI, 451-452); stalowy (stal 'stop żelaza z węglem i innymi pierwiastkami' SJPSz III, 294; stalowy 'mający kolor stali, szaroniebieski, czasem z metalicznym połyskiem' SJPSz III, 295);

d) nazwy barw motywowane nazwami roślin:

należące do pola czerwieni: truskawkowa czerwień (truskawka 'owoc rośliny z rodziny różowatych, najczęściej koloru czerwonawego’ SJPSz III, 500);

należące do pola zieleni: miętowy (mięta 'roślina w rodziny wargowych występująca w wielu gatunkach, z których takie jak mięta pieprzowa i kędzierzawa są uprawiane i dostarczają olejku miętowego, mającego zastosowanie w przemyśle

12 Magdalena Hildebrand, red., Mineraty i kamienie szlachetne. Podręczny leksykon przyrodniczy, tłum. Małgorzata Frączyk (Warszawa: Wydawnictwo Horyzont, 2002), 84. 
farmaceutycznym, cukierniczym i perfumeryjnym' SJPD IV, 680); limonkowy (limonka 'owoc limy o żółtozielonej barwie' SJP PWN online); oliwkowy (oliwka 'owoc barwy zielonej' SJPSz II, 495); pistacjowa zieleń (pistacja 'owoc drzewa pistacjowego o zielonej barwie' SJPSz II, 650);

należące do pola żółci: bananowa żótć (banan 'owoc rośliny z rodziny bananowatych o żółtej barwie' SJPD I, 329); cytrynowy, cytrynowy żólty (cytryna 'owoc o grubej, jasnożółtej skórce’ SJPD I, 1083); wanilia (wanilia 'pnącze nadrzewne o jajowatych liściach, żółtozielonych kwiatach i długich, cienkich owocach, rosnące w Ameryce Południowej i Środkowej; też: owoc tej rośliny’ SJP PWN online); należące do pola barwy niebieskiej: chabrowy (chaber bławatek 'chwast polny o kwiatach niebieskich' SJPSz I, 232); granat, granatowy (granat 'owoc granatowca o czerwonym miąższu'13 SJPSz I, 650);

należące do pola fioletu: fiołek (fiołek 'roślina zielna o kwiatach najczęściej fioletowych' SJPSz I, 554); hiacyntowy fiolet (hiacynt 'roślina z rodziny liliowatych hodowana dla pięknych, pachnących kwiatów'14 SJPD III, 68); lawenda, lawendo$\boldsymbol{w y}$ (lawenda 'krzew lub krzewinka z rodziny wargowych o kwiatach niebieskofioletowych i owłosionych liściach' SJPSz II, 15); liliowy (lilak 'krzew lub niskie drzewo z rodziny oliwkowatych, o wonnych kwiatach fiołkowych, lila lub białych, zebranych w gęste wiechy' SJPSz II, 33); kolor baktażanu (bakłażan 'owoc rośliny z rodziny psiankowatych o kształcie wydłużonym, koloru fioletowoczarnego' SJPSz I, 108); śliwkowy, śliwkowy fiolet, dojrzala śliwka (śliwka 'owoc śliwy' SJPD VIII, 1270; śliwkowy 'mający kolor ciemnofioletowy lub fioletowoczerwony, taki jak niektóre odmiany śliwek' SJP PWN online);

należace do pola pomarańczu: morela, morelowy (morela 'owoc drzewa moreli zwyczajnej’ SJPSz II, 202; morelowy 'mający kolor dojrzałej moreli - różowy z odcieniem żółtawym’ SJPSz II, 202); soczysta sycylijska pomarańcza (pomarańcza 'owoc drzewa z rodziny rutowatych o dużych, soczystych owocach' SJPSz II, 757; pomarańczowy 'mający barwę owoców pomarańczy, żółty z czerwonawym zabarwieniem' SJPSz II, 757);

należące do pola różu: amarantowy (amarant 'roślina o kwiatach różowoczerwonych z odcieniem fioletowym' SJPSz I, 38); fuksja, fuksjowy (fuksja 'roślina krzewiasta z rodziny wiesiołkowatych, o ozdobnych kwiatach, najczęściej biało-czerwonych'15 SJPD II, 988); malinowy (malina 'krzew o kolczastych pędach i drobnych, różowoczerwonych owocach' SJP PWN online);

13 Bardzo dojrzałe owoce granatu przybierają barwę ciemnoczerwoną z domieszką niebieskiego i fioletu, stąd prawdopodobnie określenie tą nazwą barwy ciemnoniebieskiej.

${ }^{14}$ Hiacynty to rośliny o różnokolorowych kwiatach, m.in. czerwonych, białych, niebieskich i fioletowych.

15 W jednym z przytoczonych cytatów możemy natomiast przeczytać: Na oknach pochylaty sięczerwonofioletowe fuksje, białe firaneczki osłaniaty szyby (Was. W. Gwiazdy 294). 
e) nazwy barw motywowane nazwami potraw i napojów:

należące do pola bieli: kremowy (krem 'lekka, gęsta masa ubita lub utarta ze śmietany, śmietanki, białka albo masła z cukrem i przyprawami’ SJPD III, 1118);

należące do pola czerwieni: bordo, bordowy (fr. Bordeaux - region winiarski we Francji, słynący z produkcji czerwonego wina); burgund, burgundowy, szlachetny odcień burgundu (fr. Bourgogne - region winiarski we Francji, słynący z produkcji wina); czerwony szafran (szafran 'ciemnopomarańczowy proszek otrzymywany z wysuszonych znamion słupka kwiatu szafranu, stosowany jako przyprawa i barwnik do ciast, wódek gatunkowych itp.' SJPSz III, 363);

należące do pola żółci: miodowy, miodowa żótć (miód 'produkt z nektaru kwiatowego lub spadzi wytwarzany głównie przez pszczoły' SJPSz II, 175; miodowy 'mający kolor miodu, złotawy' SJPSz II, 174); musztardowy, musztardowy odcień zóttego (musztarda 'ostra przyprawa sporządzana ze zmielonych nasion gorczycy z dodatkami smakowymi oraz przyprawami ziołowo-korzennymi’ SJPSz II, 219); pikantne curry, źótte curry (curry 'mieszanina zmielonych przypraw korzennych (m.in. pieprzu, kardamonu, kurkumy, imbiru) używana jako przyprawa' SJPSz I, 296 - curry jest przyprawą o barwie żółtej); aromatyczna kurkuma (kurkuma 'wyciąg z korzenia rośliny należącej do imbirowatych dający aromatyczne olejki, krochmal i żółty barwnik, stosowany w przemyśle spożywczym, lecznictwie, farbiarstwie SJPD III, 1310);

należące do pola brąu: cynamonowy (cynamon 'suszona kora cynamonowca cejlońskiego lub cynamonowca kasji sprzedawana w formie brązowych rurkowato zwiniętych laseczek’ SJPSz I, 301).

W grupie nazw barw powstałych od nazw potraw, napojów i przypraw znalazły się ponadto nazwy stanowiące luźne skojarzenia autorki bloga na temat poszczególnych barw. Do takich nazw zaliczają się: kolor czerwonego wina, kolor francuskiego wina, barwa złamana kropla czerwonego wina - przywołujące w umysłach czytelników kolory bordo oraz burgund, a także bardzo oryginalne nazwy, jak np.: kolor drinka Tequila Sunrise (tak określone okulary mienią się kolorami tęczy: żółtym, czerwonym oraz pomarańczowym; dodatkowo odbijają kolory stroju Macademian Girl - róż i fiolet), kolor zmrożonego sorbetu mango (sukienka w tym kolorze jest intensywnie żółta jak miąższ owocu mango) czy kolor pianek marshmallows (określona w ten sposób torebka jest trójkolorowa - żółta, różowa i błękitna; wszystkie kolory są blade, pastelowe, rozbielone i przypominają te, jakie używane są do produkcji popularnych słodyczy).

f) nazwy barw motywowane nazwami artefaktów:

należące do pola czerwieni: ceglasta czerwień (ceglasty 'mający kolor wypalanej cegły; pomarańczowoczerwony’ SJPSz I, 220);

należące do pola brazu: rudość, rudy (rudzi, rdzawy 'mający kolor rdzy, brunatnoceglasty’ SJPSz III, 23); 
należące do pola różu: pudrowy róż oraz pudrowy - jako skrócenie tej nazwy (róż 'środek kosmetyczny do malowania rumieńców' SJPSz III, 129);

należące do pola szarości: popielaty (popiót 'pozostałość w stanie stałym (szary proszek) po spaleniu substancji pochodzenia organicznego jak: tlenki, fosforany, siarczany, węglany' SJPD VI 1008).

W tej grupie pojawia się również niezwykle obrazowe określenie barwy błękitnej - w opisie koloru letnich sandałów, które blogerka opisała poprzez porównanie: błękitne jak basen w pięciogwiazdkowym hotelu. Buty w tym kolorze są jasnoniebieskie, a przy tym mienią się niczym tafla wody muskana promieniami słońca.

g) nazwy barw motywowane nazwami atrybutów człowieka i zwierząt:

należące do pola czerwieni: krwista czerwień (krew 'płyn odżywczy koloru czerwonego, krążący w organizmie' SJPD III, 1187) - nazwa odnosząca się do prototypowych konotacji barwy czerwonej, wiązanej z krwią;

należące do pola żółci: soczyście kanarkowy odcień (kanarek 'mały ptak z rodziny łuszczaków, żyjący dziko na Wyspach Kanaryjskich, w Europie hodowany w klatkach dla pięknego śpiewu; rasy hodowlane odznaczają się żółtym upierzeniem’ SJPD III);

należące do pola brązu: $\boldsymbol{b} e \dot{z}$ (beż 'kolor piaskowożółty, szarożółty, barwy mlecznej kawy' SJPD I, 470; 'barwa naturalna wełny owczej, tkanina z wełny nie farbowanej'; fr. laine beige = wełna naturalna, nie farbowana $\left.{ }^{16}\right)$;

należące do pola pomarańczu: nude (ang. nude = cielisty, w kolorze ciała);

h) nazwy barw motywowane zjawiskami natury:

należące do pola bieli: śnieżna biel, śnieżnobiały, biały jak śnieg - barwa biała definiowana jest zwykle z kwalitatywnego punktu widzenia z przywołaniem wzorców takich jak śnieg, mleko oraz sól ${ }^{17}$;

należące do pola czerwieni: ognista czerwień, ognistoczerwony, ogniście czerwony; płomienna czerwień, ptomienny - odnoszące się do prototypowego wzorca barwy czerwonej, czyli ognia' ${ }^{18}$;

należące do pola żółci: stonecznie żótty, stoneczny - przywołujące asocjacje ze światłem słonecznym, słońce jest bowiem referencją prototypową tej barwy.

Ciekawe w tym zestawieniu jest również wprowadzenie nazwy opisowej kolor $\boldsymbol{z} \boldsymbol{a}$ chodzacego słońca, która mieści się zarówno w polu żółci, jak i czerwieni oraz pomarańczu. Wzór kraty na płaszczu o tej barwie łączy w sobie wszystkie wymienione wyżej kolory.

${ }^{16}$ Andrzej Bańkowski, Etymologiczny stownik języka polskiego, t. I (Warszawa: Wydawnictwo Naukowe PWN, 2000), 44.

17 Tokarski, Semantyka barw, 41.

18 Tamże, 27. 
i) nazwy barw motywowane przyrodą ożywioną i nieożywioną: należące do pola zieleni: morski, odcień morskiej toni, morska zieleń (morski 'kolor zielononiebieski' SJPD IV, 84-842); barwa oszronionych liści stanowiąca połączenie zgaszonej, rozbielonej zieleni oraz szarości; należące do pola barwy niebieskiej: barwa zimowego nieba, kolor nieba, kolor błękitnego nieba - barwa niebieska prototypowo konotuje skojarzenia z niebem, warto jednak zwrócić uwagę, że w każdym z trzech przykładów odcień będzie nieco inny. Barwa zimowego nieba to połączenie błękitu, szarości, a nawet zieleni; kolor błękitnego nieba jest intensywnie błękitny, kojarzący się ze słonecznym dniem; natomiast kolor nieba jest delikatnie niebieski, nieco rozbielony i przygaszony;

j) nazwy barw motywowane nazwami geograficznymi i nazwami osób noszących charakterystyczny strój:

należące do pola czerwieni: cesarska czerwień, czyli intensywny, głęboki czerwony kolor. Czerwień to kolor władzy i siły, to również kolor stroju chińskich cesarzy, który był bezpośrednim skojarzeniem dla blogerki. Czerwień jest symbolem wielkiego czynu, walki i zwycięstwa, jest utożsamiana z siłą i władzą. Dookreślenie tej barwy przymiotnikiem cesarski potęguje w umyśle odbiorców symbolikę przypisywaną czerwieni (władza, siła), a jednocześnie budzi nowe skojarzenia, takie jak dostojność, wytworność, bogactwo;

należace do pola fioletu: indyjski fiolet to soczyście fioletowy odcień, który blogerce przywiódł na myśl orientalne podróże. Skojarzenie z Indiami jest bardzo zasadne - na każdym indyjskim targowisku wzrok przykuwają kolorowe barwniki, które wykorzystuje się zarówno do barwienia tkanin, jak i podczas obchodów Holi, czyli święta radości i wiosny, w czasie którego uczestnicy obrzucają się wzajemnie barwnymi proszkami. Być może powiązanie tego konkretnego odcienia z Indiami dokonało się poprzez obserwację hinduskich strojów kobiecych, pośród których fioletowe sari cieszy się dużą popularnością.

Wśród 10 klas obiektów, które dla autorki bloga stały się podstawą do nazywania poszczególnych kolorów, najbardziej produktywna okazała się grupa nazw motywowanych nazwami roślin (24 jedn. leks., 20\% badanego materiału). Przeprowadzona analiza potwierdziła w tym miejscu założenia Ryszarda Tokarskiego, który wskazywał, że świat roślinny jest tym kręgiem pojęciowym, który szczególnie intensywnie kreuje nazewnictwo kolorystyczne $^{19}$. W grupie tej dominują określenia tworzone od nazw owoców (12), jak limonkowy, granatowy, dojrzała śliwka czy soczysta sycylijska pomarańcza oraz nazw kwiatów (7), np. amarantowy, fiołek, fuksja. Zaskakująca - choć współcześnie dość rozpowszechniona wydaje się nazwa kolor bakłażana, ponieważ w historii nazewnictwa barw rzadko spotyka się odniesienia do warzyw (wyjątek stanowią tu nazwy takie jak buraczkowy, marchewkowy czy groszkowy). To owoce - soczyste i aromatyczne - stanowią najbardziej płodną

19 Tamże, 147. 
grupę. Jednakże intensywnie fioletowy kolor bakłażana, a także jego połyskująca, mieniąca się w słońcu skórka sprawiły, że w polszczyźnie zaczął funkcjonować kolor bakłażanowy, którym Macademian Girl określiła skórzane rękawiczki. Wiele przywołanych nazw barw zostało utworzonych od nazw używanych niegdyś barwników (14), jak np. karminowy, kobaltowy, ochra, oranż. Liczne są również odniesienia do codziennych doświadczeń człowieka, jak np. określenia tworzone od nazw potraw i napojów (13), wśród których najliczniejszą podgrupę stanowią nazwy przypraw (6), jak aromatyczna kurkuma, pikantne curry czy cynamonowy. Blogerka chętnie wykorzystuje również odniesienia do nazw minerałów i kamieni szlachetnych (7) oraz metali szlachetnych (7): ametystowy, rubinowy, szmaragdowy oraz miedziany, srebrny, złoty. W zestawieniu pojawia się ponadto kilka bardzo oryginalnych nazw barw, które są efektem skojarzeń autorki na temat otaczającego ją świata. Do takich nazw należą m.in. kolor zmrożonego sorbetu mango, kolor drinka Tequila Sunrise, barwa oszronionych liści czy kolor zachodzącego słońca.

\section{3.}

Bogactwo zastosowanych określeń kolorystycznych dowodzi niezwykłej wrażliwości $M a-$ cademian Girl na zjawisko barw. Tamara Gonzalez Perea dostrzega nawet najdrobniejsze różnice w tonacjach i nasyceniu poszczególnych kolorów. Zwraca uwagę na niuanse, odróżnia subtelne odcienie, z wyjątkowym znawstwem łączy kolory. Niewątpliwie przyczyniły się do tego studia na Akademii Sztuk Pięknych, które blogerka rozpoczęła w Poznaniu, a zakończyła w rodzinnym Szczecinie. Jak sama powiedziała w jednym z wywiadów, dzięki studiom artystycznym zyskała dużą wrażliwość na otoczenie i kompozycję, a strój zaczęła traktować jako swoiste dzieło sztuki, obraz, za pomocą którego może wyrazić swoją osobowość $^{20}$. W postach publikowanych na blogu Macademian Girl ważny jest nie tylko obraz, ale również, a może przede wszystkim, płaszczyzna językowa. Autorka koncentruje się na takim sposobie językowego prezentowania swoich stylizacji, by przed oczami internautów ukazały się malownicze ilustracje. Przywołuje skojarzenia, które przywodzą na myśl orientalne krainy, królewskie rezydencje czy egzotyczne ogrody. Wykreowane przez nią stroje są zawsze interpretacją otaczającej ją rzeczywistości, stąd częste odwołania np. do świata przyrody: Nadruk jak akwarela z japońskiego ogrodu kontrastuje z architektonicznym fasonem i doskonale wspótgra ze szpilkami w podobnym odcieniu (Sukienka inspirowana kwiatowym kimonem, 9 czerwca 2016) czy Kolia ze szmaragdowych kamieni i bransoletki przypominające todygi oplecione wokót nadgarstka efektownie pokreślity zieleń (Spring in El Greco, 11 kwietnia 2015). Równie częste są odwołania do sztuki, najczęściej malarskiej: Wzór na mojej sukience przypomina mi misterny witraż z irysem autorstwa czeskiego

20 Macademian Girl, „Lubię ludzi odważnych, bo bez eksperymentów nie ma mody”, Toronto: Magazyn Toruński, dostęp 28.11.2016, http://toronto-magazyn.pl. 
artysty (Wzorzysta śnieżynka, 8 stycznia 2016) oraz Dzisiaj najważniejsze sa wzory: róże i chryzantemy wyglądaja jak soczyste martwe natury z płócien Paula Cezanne'a (Kwiatowy total look, 22 lipca 2015). Skojarzenia z malarzem tworzącym dzieło budują dodatkowo nazwy barw, które są terminami stosowanymi w malarstwie: indygo, kobalt czy ochra. Ponadto Tamara Gonzalez Perea często operuje sformułowaniami, które są wręcz poetyzmami, jak choćby nazwy tworzone od nazw minerałów czy kamieni szlachetnych. Za ich pomocą stara się pobudzić czytelników do przeżycia wrażenia estetycznego, do kontemplowania dzieła sztuki, na które składa się zarówno obraz, jak i odpowiednio skonstruowany opis.

Za każdym razem kreowana przez blogerkę wizja jest skrupulatnie przemyślana, autorka doskonale wie, jakie emocje chce wywołać u swoich czytelników, jaką symbolikę przywołać, a nade wszystko jakie skojarzenia uruchomić. Dlatego tak chętnie korzysta z konstrukcji deskryptywnych, dzięki którym obraz niemal natychmiast ukazuje się oczom odbiorcy: barwa zimowego nieba, kolor nieba, kolor błękitnego nieba, odcień morskiej toni, barwa oszronionych liści, kolor zachodzacego słońca czy wreszcie błękit jak basen w pięciogwiazdkowym hotelu. Odwołuje się również do nazw produktów, które kojarzą się z dobrobytem, luksusem i wykwintnością. Kolor francuskiego wina, barwa złamana kropla czerwonego wina, kolor drinka Tequila Sunrise czy barwa pianek marshmallows mają ponadto podkreślić dobry gust i szykowność prezentowanych stylizacji. W tym samym celu autorka bloga wprowadza nazwy barw pochodzące od nazw minerałów, kamieni szlachetnych oraz kruszców i metali, jak np.: rubinowy, szmaragdowy, ametystowy, srebrny, złoty, platynowy. By subtelnie położyć akcent na doskonałą jakość i podkreślić elegancję, wykorzystuje także komponent szlachetny, to jest szlachetne indygo czy szlachetny odcień burgundu. Dzięki tym zabiegom w pewnym sensie wprowadza swoich czytelników w świat, w którym pragną się znaleźć - w świat marzeń i niedoścignionych pragnień, w przestrzeń luksusu i dostatku.

Wprowadzenie przez blogerkę tak wielu różnorodnych określeń barwnych ma również na celu zakomunikowanie odbiorcom, jak nieograniczone możliwości odkrywa przed nimi moda, ma również skłonić do zabawy trendami i do łamania obowiązujących zasad. Stosując tak rozmaite nazewnictwo, Macademian Girl subtelnie przemyca własną wizję świata mody, który cechuje się niezwykłym bogactwem i różnorodnością barw, fasonów i tkanin, i który dostarcza niemal nieograniczonych możliwości.

Warto również zauważyć, że Tamara Gonzalez Perea często sięga do sformułowań, które poza zmysłem wzroku pobudzają również inne zmysły, o czym świadczą takie nazwy jak: aromatyczna kurkuma, pikantne curry, dojrzała śliwka czy soczysta, sycylijska pomarańcza. Do tej grupy zaliczają się również wszystkie, mniej lub bardziej powszechne, nazwy derywowane od nazw owoców, które jednocześnie uruchamiają zmysły smaku i węchu: cytrynowy, malinowy, morelowy, a także oliwkowy czy kolor bakłażana. Stosując te nazwy, Macademian Girl wprowadza odpowiedni nastrój, uruchamia pozytywne emocje i optymistycznie usposabia czytelników do przekazywanych treści. 
Blogerka posiada niezwykłą zdolność formułowania opisów, które rozbudzają pozytywne emocje i napawają chęcią do działania. Zastosowanie w opisie letniej stylizacji barwy określonej jako kolor zmrożonego sorbetu mango, mimowolnie konotuje radość związaną ze słonecznym dniem. Sandałki błękitne jak basen w pięciogwiazdkowym hotelu sprawiają, że myślimy o letnim urlopie nad wodą, o relaksie i odprężeniu, a okulary w kolorze popularnego drinka Tequila Sunrise nasuwają skojarzenia z miłym wieczorem w gronie przyjaciół.

Godne uwagi jest również to, że autorka bloga, wprowadzając niepodstawowe nazwy barw o różnych odcieniach, używa w celu uszczegółowienia licznych epitetów. Kobalt jest więc kolejno: głęboki, zimny, elektryzujący; ultramaryna jest zimna; fuksja - intensywna, a kolor kanarkowy - soczysty. Tymi zabiegami potęguje pożądany efekt - paleta barw staje się jeszcze bardziej wyrazista, a najdrobniejsze niuanse kolorystyczne zostają odpowiednio podkreślone i zróżnicowane.

Wszystkie stosowane przez autorkę bloga techniki opisu poszczególnych stylizacji, w których właściwe zdefiniowanie koloru odgrywa pierwszorzędną rolę, mają na celu wskazanie czytelnikom, że styl prezentowany przez blogerkę jest godny naśladowania. Poszczególne elementy kreacji odznaczają się bowiem szykownością, dobrym smakiem i doskonałym gustem. Jak inaczej można określić stylizacje, które są swoistym zapisem największych dzieł sztuki lub odzwierciedleniem dalekich, egzotycznych podróży? Tamara Gonzalez Perea jest niezwykle świadoma możliwości, jakie otwiera przed nią język, co powoduje, że fotografie, które pojawiają się pod treścią postu, są jedynie dodatkiem do barwnego opisu słownego.

\section{Bibliografia}

Bańkowski, Andrzej. Etymologiczny słownik języka polskiego. T. I-III. Warszawa: Wydawnictwo Naukowe PWN, 2000.

Berlin, Brent, Paul Kay. Basic Color Terms: Their Universality and Evolution. Berkeley: University of California Press, 1969.

Doroszewski, Witold, red. Stownik języka polskiego. T. I-XI. Warszawa: Państwowe Wydawnictwo „Wiedza Powszechna", 1958-1969.

Hildebrand, Magdalena, red. Minerały i kamienie szlachetne. Podręczny leksykon przyrodniczy. Tłum. Małgorzata Frączyk. Warszawa: Wydawnictwo Horyzont, 2002.

Komorowska, Ewa. Barwa w języku polskim i rosyjskim: rozważania semantyczne. Szczecin: Wydawnictwo Naukowe Uniwersytetu Szczecińskiego, 2010.

Macademian Girl, „Lubię ludzi odważnych, bo bez eksperymentów nie ma mody”. Toronto: Magazyn Toruński. Dostęp 28.11.2016. http://toronto-magazyn.pl.

Madeja, Agnieszka. „Skąd pochodzą polskie nazwy kolorów”. Postscriptum Polonistyczne 2 (2010): 197217.

Szymczak, Mieczysław, red. Stownik języka polskiego PWN. T. I-III. Warszawa: Wydawnictwo Naukowe PWN, 1996. 
Tokarski, Ryszard. „Nazwa barwy i jej użycia prototypowe”. W: Opisać słowa, red. Andrzej Markowski, 202-221. Warszawa: Wydawnictwo „Elipsa” 1992.

Tokarski, Ryszard. Semantyka barw we współczesnej polszczyźnie. Lublin: Wydawnictwo UMCS, 2004.

Zaręba, Alfred. Nazwy barw w dialektach i historii języka polskiego. Wrocław: Zakład Narodowy im. Ossolińskich, 1954.

\section{Sukienka w kolorze zmrożonego sorbetu mango - czyli kilka słów o barwach na blogu modowym Macademian Girl}

Streszczenie

Celem niniejszego artykułu była analiza i interpretacja niepodstawowych nazw barw, które wyekscerpowano z 91 postów zamieszczonych na blogu modowym Macademian Girl, czyli Tamary Gonzalez Perei, w okresie od 3 stycznia 2015 roku do 9 czerwca 2016 roku. Klasyfikacji materiału badawczego dokonano na podstawie podziału znaczeniowych źródeł niepodstawowych nazw barw zaproponowanego przez Ryszarda Tokarskiego, który rozbudowano o inne typy motywacji, jakie ujawniły się w toku prowadzonej analizy. Wyekscerpowany do analizy materiał stanowiło łącznie 117 leksemów, które autorka bloga zastosowała w 322 realizacjach tekstowych. Wśród analizowanych jednostek językowych znalazły się pojedyncze leksemy, konstrukcje analityczne, a także struktury deskrypcyjne, wyrażane najczęściej w formie porównań.

Przeprowadzona analiza wykazała, że Tamara Gonzalez Perea wykazuje niezwykłą wrażliwość na zjawisko barw - dostrzega drobne różnice w tonacjach i nasyceniu poszczególnych kolorów, zwraca uwagę na niuanse, odróżnia subtelne odcienie, z wyjątkowym znawstwem łączy kolory. Interpretacja wyekscerpowanego materiału pozwoliła wykazać, że wszystkie zastosowane przez autorkę bloga techniki opisu poszczególnych stylizacji, w których właściwe zdefiniowanie koloru odgrywa pierwszorzędną rolę, mają na celu wskazanie czytelnikom, że styl prezentowany przez blogerkę jest godny naśladowania, szykowny i modny. Macademian Girl celowo i świadomie wykorzystuje możliwości, jakie otwiera przed nią język, co powoduje, że to właśnie opis słowny - nie fotografia - zaczyna odgrywać pierwszoplanową rolę.

\section{A frozen mango sorbet coloured dress: A few remarks on colours on the fashion blog by Macademian Girl}

Su m m ary

The purpose of the article is the analysis and interpretation of the non-basic colour names, excerpted from 91 posts published on the fashion blog by Macademian Girl, i. e. Tamara Gonzalez Perea, from 3rd January 2015 to 9th June 2016. The classification of the research material was made based on the division of the semantic sources of the non-basic names of colours proposed by Ryszard Tokarski, supplemented with the other types of motivation, revealed during the analysis. The material excerpted for analysis comprised together 117 lexemes used by the author 
in 322 text realisations. The analysed linguistic units included the single lexemes, analytic constructions, and the descriptive structures expressed most frequently in the form of comparisons. The performed analysis demonstrated that Tamara Gonzalez Perea displays a remarkable sensitivity to colours. She perceives slight differences in colour schemes and saturation, pays attention to nuances, distinguishes subtle hues, and matches colours with excellent expertise. The interpretation of the excerpted material has shown that all the description techniques used by the author to depict the particular fashion creations in which the proper defining of colour is of primary importance, are intended to convince the readers that the style presented by the blogger is worth imitating, smart, and fashionable. Macademian Girl deliberately and consciously takes advantage of the possibilities offered by language, as a result of which it is the verbal description - and not the photography - that begins to play a crucial role. 